\title{
Overexpression of APCII predicts worse survival in lung adenocarcinoma [Corrigendum]
}

Zhou J, Zhang S, Fu G, et al. Onco Targets Ther. 2018;11:7125-7132.

Author intended to show unrepresentative images of cell migration and invasion, that the number of migration cells was similar with invasion cells in Figure 4, page 7129.

The published image for Figure 4B was not consistent with the author's expectation. Author repeated the assay test and received better and reasonable images for replacement. These replacement of images to Figure $4 \mathrm{~B}$ and $\mathrm{C}$ have not changed the overall results to the study. The author apologizes for this error.

The replacement for Figure 4 on page 7129 is shown as follow:
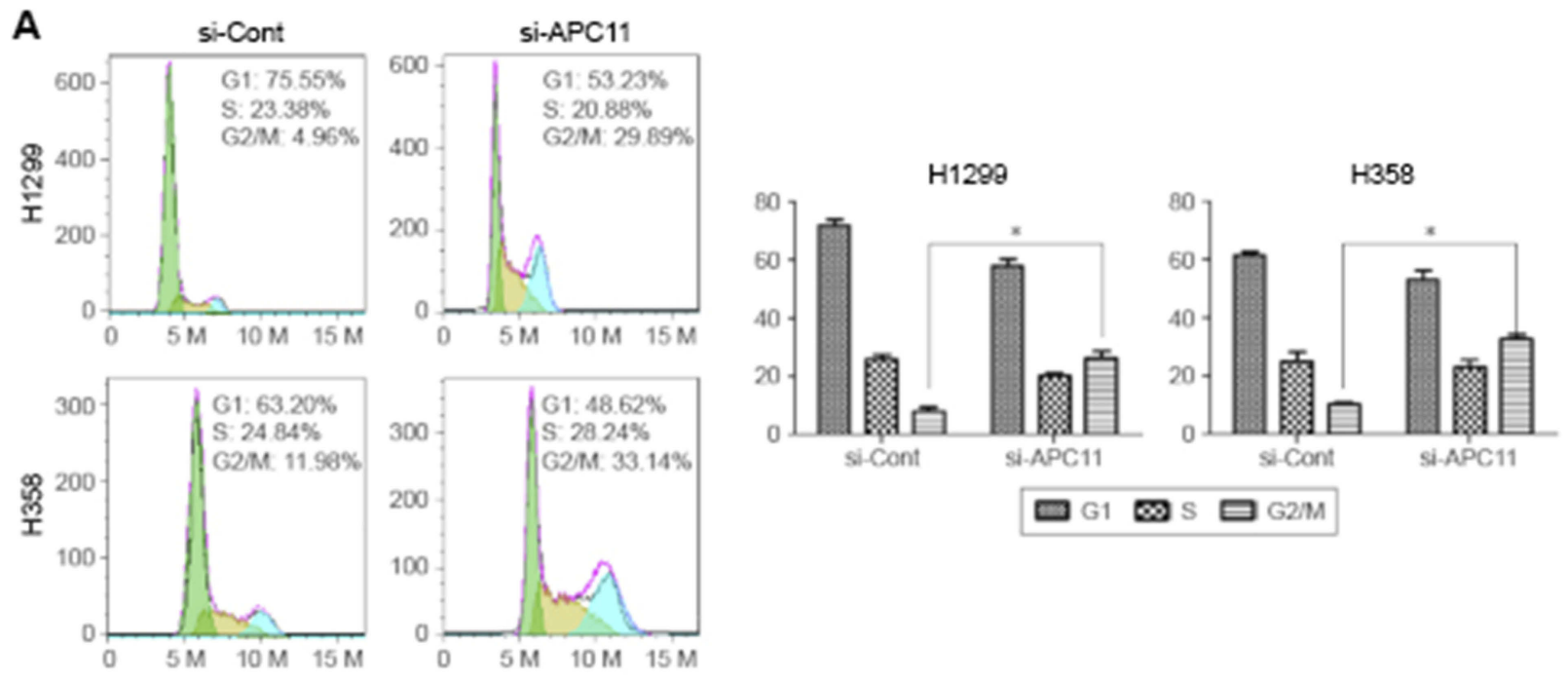

B

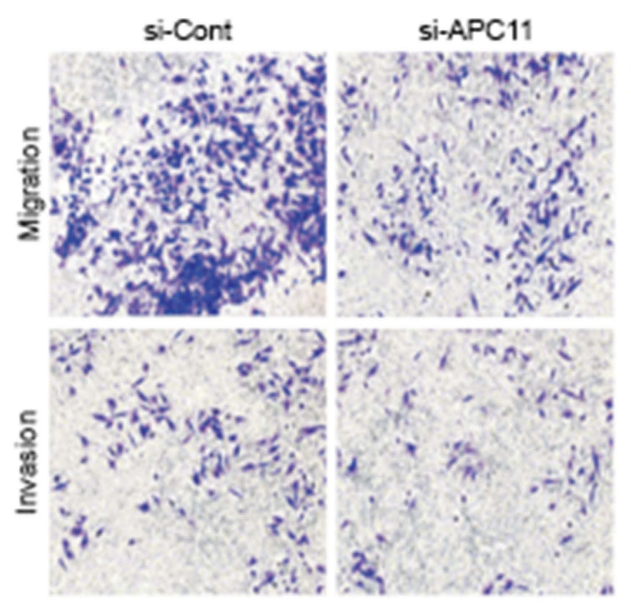

$\mathrm{H} 1299$
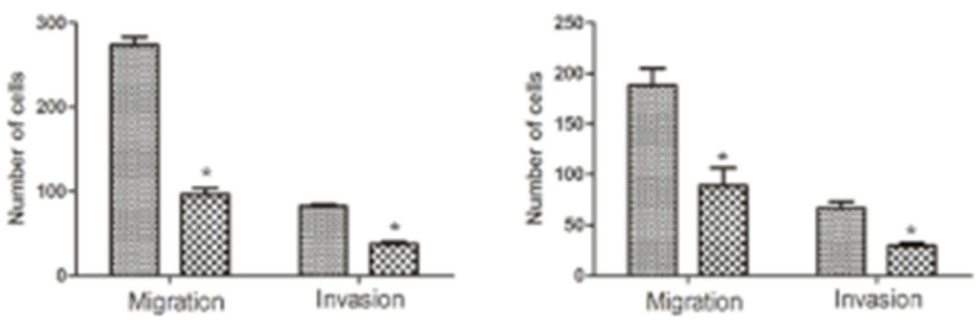

si-Cont $\mathbf{6}$ si-APC11

DovePress $f$ in $\boldsymbol{v}$

http://doi.org/|0.21 477/OTT.S212589 


\section{Publish your work in this journal}

OncoTargets and Therapy is an international, peer-reviewed, open access journal focusing on the pathological basis of all cancers, potential targets for therapy and treatment protocols employed to improve the management of cancer patients. The journal also focuses on the impact of management programs and new therapeutic agents and protocols on patient perspectives such as quality of life, adherence and satisfaction. The manuscript management system is completely online and includes a very quick and fair peer-review system, which is all easy to use. Visit http://www.dovepress.com/ testimonials.php to read real quotes from published authors.

Submit your manuscript here: https://www.dovepress.com/oncotargets-and-therapy-journal 